\title{
Sprawozdanie z III Konferencji Naukowej Wydziału Studiów Edukacyjnych UAM "O różnych drogach doskonalenia zdrowia - modele edukacji zdrowotnej w globalnym świecie" Poznań, 1 grudnia 2017 roku
}

Pracownia Edukacji Zdrowotnej Wydziału Studiów Edukacyjnych UAM zorganizowała 1 grudnia 2017 roku trzecią Konferencję Naukową "O różnych drogach doskonalenia zdrowia - modele edukacji zdrowotnej w globalnym świecie". Patronatem Honorowym objęła ją Dziekan Wydziału Studiów Edukacyjnych UAM w Poznaniu, prof. zw. dr hab. Agnieszka Cybal-Michalska. Tegoroczny temat konferencji dotyczył innowacyjnego podejścia w edukacji zdrowotnej, które warto pogłębiać i naśladować w praktyce edukacyjnej. W sprawę zapewnienia należytej rangi dla edukacji zdrowotnej w polskim systemie oświaty angażowali się od początku ludzie nauki. W stworzonym przez grono ekspertów i naukowców memoriale ku czci Wiceprezesa Rady Ministrów i Ministra Edukacji Narodowej prof. dra hab. Aleksandra Łuczaka pisali:

W naszym odczuciu szkolna edukacja prozdrowotna dzieci i młodzieży nie nadąża za gwałtownie rosnącymi zagrożeniami dla zdrowia i życia człowieka, nie zapewnia należytego przygotowania młodego pokolenia do dbałości o zdrowie własne i do działań na rzecz zdrowia publicznego. Stwarza to realne niebezpieczeństwo dalszego pogorszenia się już obecnie bardzo słabej kondycji biologicznej i psychicznej społeczeństwa, jeżeli w porę nie zostaną podjęte odpowiednie środki zaradcze ${ }^{1}$.

Problematyka konferencji wpisała się w ów nurt refleksji nad problematyką edukacji zdrowotnej we współczesnym świecie.

Powitania uczestników dokonała dr Ewa Kasperek-Golimowska, która przewodniczyła Komitetowi Organizacyjnemu, natomiast Konferencja została oficjalnie otwarta przez Panią Dziekan, prof. zw. dr hab. Agnieszkę Cybal-Michalską. Przywitała ona zgromadzonych studentów Uniwersytetu im. Adama Mickiewicza w Poznaniu wraz z zaproszonymi wykładowcami, wyrażając swoje uznanie wobec odbywającego się wydarzenia. W swoim wystąpieniu zwróciła uwagę, że konferencja ma charakter cykliczny, a jej poprzednie edycje odniosły wielki sukces. Podkreśliła również rolę problematyki dotyczącej edukacji zdrowotnej w obszarze współczesnej pedagogicznej refleksji naukowej.

W tematykę obrad konferencyjnych wprowadziła słuchaczy dr Ewa Kasperek-Golimowska. Jako pierwsza wystąpiła prof. zw. dr hab. Agnieszka Gromkowska-Melosik (Prodziekan WSE ds. Studiów Doktoranckich i Współpracy Międzynarodowej, Kierownik Zakładu Edukacji Wielokulturowej i Ba-

1 „Lider” 1995, nr 6, s. 6-7. Memoriał podpisali: prof. dr hab. Maciej Demel, prof. dr hab. Zygmunt Jaworski, prof. dr hab. n. med. Aleksander Kabsch, prof. dr hab. Zofia KawczyńskaButrym, prof. dr hab. Roman Trześniowski, prof. dr hab. n. med. Barbara Woynarowska, prof. dr hab. n. med. Witold Zatoński, prof. dr hab. n. med. Światosław Ziemiański. 
dań nad Nierównościami Społecznymi WSE UAM) z referatem zatytułowanym „Kultura jedzenia i «kultura ciała» - edukacja wobec zaburzeń odżywiania się”. Dotyczył on wnikliwego spojrzenia na problematykę wspomnianych zaburzeń, szczególnie w kontekście współczesnej kultury młodzieżowej i popularnej. Prelegentka podkreśliła także rolę nauczyciela jako osoby „pierwszego kontaktu” w diagnozowaniu problemów zdrowotnych swoich podopiecznych, których ponad wszystko powinniśmy jako pedagodzy wspierać. Prezentacja kluczowych strategii nauczycielskich w kontekście podejmowania problemów związanych z zaburzeniami odżywiania się była mocnym akcentem wystąpienia i spotkała się z dużym zainteresowaniem w trakcie dyskusji. Z kolei, dr hab. Agnieszka Krzymińska, Kierownik Katedry Roślin Ozdobnych Uniwersytetu Przyrodniczego w Poznaniu, wygłosiła wykład zatytułowany „Hortiterapia - metoda wspomagająca leczenie tradycyjne”, który ukazał nowe alternatywne metody terapii, także wykorzystywane w działaniach pedagogicznych. Następnie wystąpiła dr n. hum. Agata Woźniak, która podjęła temat: „Od zdrowego myślenia do zdrowego zachowania. Zastosowanie technik poznawczo-behawioralnych w praktyce pedagogicznej". Przedstawione w nim rozwiązania z dziedziny edukacji prozdrowotnej z pewnością okażą się inspiracją dla słuchaczy, którzy są zainteresowani socjoterapią i promocją zdrowia. Pierwszą część Konferencji zamknął referat dra filozofii Marcina Fabjańskiego, twórcy Apenińskiej Szkoły Żywej Filozofii w Trevi Nel Lazio. Jego wykład nosił tytuł „Troska o zdrowie poprzez dostrojenie medytacyjne do natury, refleksje praktyka i podsumowanie nowych badań". Ukazując, bez wątpienia, nietypowo perspektywę edukacji zdrowotnej połączonej z medytacją oraz ideą mindfullnes, na długo zapadnie w pamięci uczestników.

Druga część Konferencji dotyczyła różnorodnych modeli, koncepcji i projektów należących do obszaru edukacji zdrowotnej w Polsce i na świecie. Moderatorem tej sekcji była dr Anna Gulczyńska wraz dr Jolantą Twardowską-Rajewską. Uczestnicy mogli wysłuchać następujących wystąpień: „Profilaktyka w szkole wielka nie(d)oceniona moc sprawcza" (Barbara Michalska i Agata Kobylińska); "Zadowolenie z zaangażowania w sport w teorii i praktyce" (Magdalena Kaczmarek); "Edukacja prozdrowotna w Irlandii” (dr n. med. Anna Ignyś-O’Byrne); „Lekarze bez granic w Tanzanii” (prof. zw. dr hab. n. med. Jan Skrzypczak); "Profilaktyka gerontologiczna - edukacja pacjenta w Polsce i innych krajach” (dr n. med. Jolanta Twardowska-Rajewska); "Nauczyciele-rodzice - jak rozmawiać o rozwiązaniach” (dr n. hum. Anna Gulczyńska); „Promowanie zdrowia wśród dzieci poprzez różne formy działalności studenckiej" (Dominika Hoft, Florentyna Szofer i Kinga Woźniak - studentki pedagogiki). Wykładem zamykającym drugą część Konferencji była prelekcja dr n. hum. Ewy Kasperek-Golimowskiej, Kierownika Pracowni Edukacji Zdrowotnej Wydziału Studiów Edukacyjnych UAM, na temat: „Tradycyjne i nowoczesne modele edukacji zdrowotnej”.

Podsumowaniem tej części była dyskusja dotycząca form popularyzacji edukacji zdrowotnej w Polsce oraz innych krajach Europy i świata. Konferencja była szansą podjęcia refleksji i wymiany spostrzeżeń na temat szeroko rozumianej problematyki ludzkiego zdrowia. Ważnym celem Konferencji był walor aplikacyjny przedstawionych zagadnień, szczególnie w kontekście funkcjonowania szkoły. 
W wielu wystąpieniach znalazły się wątki dotyczące praktycznych działań nauczycielskich i propozycje udoskonalenia programów edukacji zdrowotnej.

Wydarzenie zgromadziło wielu słuchaczy, którzy z zaciekawieniem odbierali wystąpienia prelegentów oraz uczestniczyli w burzliwych $\mathrm{z}$ nimi debatach (nawet podczas przerw). Ukazuje to zatem, że spotkania takie organizowane są z potrzeby naukowców, studentów oraz wykładowców-praktyków, aby wspólnie wypracować sposoby, które wpłyną na jakość edukacji zdrowotnej w szkołach oraz innych placówkach oświatowych. Pozytywne nastawienie i zaangażowanie władz uczelni, jak również uczestników konferencji „mówi” mi, że za rok będzie nam dane uczestniczyć w kolejnej - czwartej już edycji. 